Філоненко С. В., кандидат сільськогосподарських наук

Полтавська державна аграрна академія

\title{
ПРОДУКТИВНІСТЬ І ТЕХНОЛОГІЧНІ ЯКОСТІ КОРЕНЕПЛОДІВ БУРЯКА ЦУКРОВОГО ЗАЛЕЖНО ВІД ПОЗАКОРЕНЕВОГО ВНЕСЕННЯ РЕГУЛЯТОРА POCTУ «MAPC-1»
}

\section{Рецензент - кандидат сільськогосподарських наук С. В. Поспєлов}

Регулятори росту і розвитку рослин стають важливою складовою сучасних технологій вирощування сільськогосподарських культур. Автором вивчено закономірності впливу позакореневого внесення регулятора росту «Марс-1» на формування врожайності та якості коренеплодів буряка иукрового гібриду Іванівсько-Веселоподільський ЧС 84 . Рекомендовано застосовувати «Марс-1» двічі: периий раз - у фазі чотирьох пар справжніх листків, другий - перед змиканням листя у міжряддях. Доза для кожного внесення - 0,8 л/га.

Ключові слова: буряк иукровий, регулятор росту, гібрид, иукристість, збір иукру, листкова поверхня, фази розвитку, дози внесення, врожайність.

Постановка проблеми. Одним із нових агрозаходів сучасної технології вирощування буряка цукрового $\epsilon$ застосування регуляторів росту. Використання таких препаратів у буряківництві визнане досить ефективним і суттєвим резервом збільшення врожайності культури та підвищення цукристості її коренеплодів. Саме тому застосування регуляторів росту у світовому землеробстві стає неодмінною ланкою нових ресурсозберігаючих технологій вирощування сільськогосподарських культур, у тому числі й буряка цукрового [4].

У цілому регулятори росту використовуються для обробки посівного матеріалу та вегетуючих рослин: вони є надійним чинником поліпшення біологічних властивостей насіння та продуктивності посівів. Не дарма сучасні біостимулюючі препарати визнані одним із найдешевших засобів, здатних забезпечити суттєве підвищення врожайності культур.

Сільськогосподарському виробнику промисловість пропонує цілу низку нових регуляторів росту. На жаль, вичерпних достовірних даних про вплив цих препаратів на продуктивність тієї чи іншої культури, в тому числі й буряка цукрового, у конкретних виробничих умовах певної грунтово-кліматичної зони мало. Все це й обумовило доцільність та необхідність проведення відповідних досліджень.
Аналіз основних досліджень і публікацій, у яких започатковано розв'язання проблеми. Одним із головних напрямів розвитку аграрного сектора в Україні $\epsilon$ інтенсифікація виробництва, застосування нових прогресивних технологій, які дають змогу підвищувати врожайність і стійкість сільськогосподарських культур до несприятливих чинників довкілля. Складовою цього напряму є розробка методів екзогенної регуляції та стабілізації адаптивних реакцій рослин завдяки використанню фізіологічно активних речовин синтетичного та природного походження.

За останні $10-15$ років на основі найновітніших наукових досягнень у хімії й біології, як стверджує Т. В. Засуха (2001), були створені принципово нові високоефективні регулятори росту рослин (РРP), спроможні істотно підвищувати врожаї сільськогосподарських культур. Результати широкої наукової перевірки показали, що впровадження сучасних регуляторів росту може сприяти значній інтенсифікації сільськогосподарського виробництва [3].

Регулятори росту рослин - широкий термін, що включає природні (ендогенні), синтетичні (екзогенні), біологічно активні та хімічні сполуки. Регулятори росту і розвитку рослин стають важливою складовою сучасних інтенсивних технологій вирощування сільськогосподарських культур у нашій державі. Проте регулятори росту - не універсальний засіб, що викликає з'явлення у рослин нових якостей продукції [5]. Як зазначає С. П. Пономаренко (2008), регулятори росту ні в якому разі не замінять добрива, вони можуть лише активізувати фізіологічно важливі процеси розвитку рослин. Більше того, регулятори росту відносяться до хімічних засобів управління біологічними процесами, що відбуваються в рослинах. Застосування цих препаратів регламентується тими ж інструкціями, що й застосування пестицидів [6].

Які ж переваги застосування регуляторів росту рослин? По-перше, відчутно зменшується мутагенна дія гербіцидів та інших антропогенних чинників. По-друге, завдяки регуляторним меха- 


\section{СІЛЬСЬКЕ ГОСПОДАРСТВО. РОСЛИННИЦТВО}

нізмам посилюється розвиток листкової поверхні. Регулятори росту рослин активізують основні процеси життєдіяльності рослин: мембранні процеси, поділ клітин, ферментні системи, фотосинтез, процеси дихання і живлення. Під впливом регуляторів росту створюється розгалужена коренева система, яка має набагато більшу поглинальну спроможність [7].

Важливим $\epsilon$ i те, що регулятори росту рослин сприяють підвищенню біологічної та господарської ефективності рослинництва, зниженню вмісту нітратів, іонів важких металів і радіонуклідів у кінцевій продукції. Завдяки РРР інтенсифікується розвиток азотфіксуючих і фосфатмобілізуючих бактерій. Крім того, регулятори вирізняються значною антистресовою дією, що доведено численними дослідами вітчизняних і світових науковців [1].

Суттєвого значення регулятори росту рослин, як стверджує М. В. Макрушин (2003), набувають у сучасних технологіях No-Till та Mini-Till, де вкрай необхідне прискорення розвитку рослин, кореневої системи, зняття стресових ефектів пестицидів. Численними дослідженнями доведено: окремі вітчизняні біостимулятори за ефективністю не поступаються відомим закордонним. За результатами багаторічної перевірки кращих українських біостимуляторів у Китаї, Росії, Нiмеччині, Казахстані та Білорусі, вони визнані, порівняно 3 іноземними, більш ефективними. Тому в цих країнах розпочато їх широке впровадження [5].

До того ж, як зазначає Л. О. Анішин (2004), вітчизняні регулятори росту рослин істотно збільшують вміст цукру в коренеплодах буряка цукрового, крохмалю в картоплі, а також підвищують схожість і енергію проростання вирощеного 3 регуляторами росту насіння, прискорюють на 5-7 днів достигання посівів культур, сприяють накопиченню більшої кількості органічної речовини в грунті та збільшенню фосфатмобілізуючих й азотфіксуючих мікроорганізмів у зоні кореневої системи [2].

За останні роки вчені синтезували значну кількість нових регуляторів росту рослин. Загальною їх властивістю, як відомо, є здатність модифікувати проникність клітинних мембран. Однак саме ця специфічність дії відповідної групи препаратів, у зв'язку з їхньою фізіологічною активністю, залишається ще недостатньо вивченою. До того ж, виявляється, що одні регулятори росту можна використовувати за певних умов, інші за таких же умов призводять до нульового, або (у гіршому випадку) - до негативного результа- ту. Крім того, не завжди доза регулятора росту, яку рекомендує реалізатор, є оптимальною для того чи іншого гібриду (сорту) відповідної культури.

Мета досліджень - вивчення впливу позакореневого внесення регулятора росту рослин «Марс-1» на продуктивність і технологічні якості коренеплодів буряка цукрового у виробничих умовах.

Завдання дослідження:

1. Провести фенологічні спостереження за фазами росту і розвитку рослин буряка цукрового залежно від застосовуваних доз регулятора росту «Мapc-1».

2. Визначити густоту рослин культури до обприскування розчином регулятора росту і перед збиранням урожаю.

3. Провести облік маси коренеплодів і гички рослин культури у три строки протягом другого періоду вегетації.

4. Дослідити динаміку наростання листкової поверхні залежно від позакореневого обприскування відповідним препаратом.

5. Вивчити вплив регулятора росту рослин «Марс-1» на врожайність коренеплодів буряка цукрового, їх цукристість та збір цукру з гектара.

Методики проведення досліджень. Польові досліди проводили протягом 2011-2012 років у сільськогосподарському товаристві з обмеженою відповідальністю «Агрофірмі ім. Суворова» Чорнухинського району Полтавської області. Грунт дослідної ділянки - чорнозем малогумусний середньосуглинковий iз вмістом гумусу 3,9\%. Метеорологічні умови за роки проведення дослідів були різноманітними й значно відрізнялися від середніх багаторічних показників.

Об'єкт досліджень - процеси формування продуктивності та якості коренеплодів буряка цукрового за позакореневого внесення регулятора росту «Марс-1». Предмет досліджень - рослини гібриду буряка цукрового ІванівськоВеселоподільський ЧС 84.

Дослідження проводилися за такою схемою:

1. Без обробки - контроль.

2. Позакореневе внесення регулятора росту «Марс-1»у дозі 0,8 л/га в фазі змикання листків у міжряддях буряка цукрового.

3. Позакореневе внесення регулятора росту «Марс-1» двічі: перший раз - у фазі чотирьох пар листків, другий - у фазі змикання листків у міжряддях. Дози внесення - по 0,8 л/га.

Загальна площа ділянки у 2011 році становила 1,1 га, облікова - 0,9 га; у 2012 році, відповідно, 1,5 і 1,3 га. Повторність досліду - триразова. 
СІЛЬСЬКЕ ГОСПОДАРСТВО. РОСЛИННИЦТВО

\section{1. Вплив позакореневого внесення регулятора росту «Марс-1» на густоту і площу листкової} поверхні рослин буряка цукрового (середнє за 2011-2012 рр.)

\begin{tabular}{|c|c|c|c|c|c|c|c|}
\hline \multirow[b]{3}{*}{ Варіанти досліду } & \multirow{2}{*}{\multicolumn{3}{|c|}{$\begin{array}{c}\text { Густота рослин, тис./га } \\
\text { строки проведення обліків }\end{array}$}} & \multirow[b]{3}{*}{$\begin{array}{l}\text { Зменши- } \\
\text { лася гус- } \\
\text { тота рос- } \\
\text { лин, \% }\end{array}$} & \multirow{2}{*}{\multicolumn{3}{|c|}{$\begin{array}{c}\text { Асиміляційна поверхня однієї } \\
\text { рослини, } \text { см}^{2}\end{array}$}} \\
\hline & & & & & & & \\
\hline & $\begin{array}{c}\text { перед } \\
\text { оброб- } \\
\text { кою }\end{array}$ & $\begin{array}{c}\text { через } 30 \\
\text { днів } \\
\text { після } \\
\text { обприс- } \\
\text { кування }\end{array}$ & $\begin{array}{c}\text { перед } \\
\text { збиран- } \\
\text { ням } \\
\text { урожаю }\end{array}$ & & $\begin{array}{c}\text { перед } \\
\text { оброб- } \\
\text { кою }\end{array}$ & $\begin{array}{c}\text { через } 30 \\
\text { днів } \\
\text { після } \\
\text { обприс- } \\
\text { кування }\end{array}$ & $\begin{array}{c}\text { перед } \\
\text { збиран- } \\
\text { ням } \\
\text { врожаю }\end{array}$ \\
\hline $\begin{array}{l}\text { 1. Без застосування } \\
\text { регулятора росту } \\
\text { (контроль) }\end{array}$ & 110,2 & 98,4 & 86,4 & 21,6 & 3065 & 3747 & 1724 \\
\hline $\begin{array}{l}\text { 2. Одноразове вне- } \\
\text { сення «Марс-1» } \\
\text { дозою } 0,8 \text { л/га }\end{array}$ & 109,6 & 104,1 & 90,1 & 17,8 & 3026 & 4139 & 1960 \\
\hline $\begin{array}{l}\text { 3. Дворазове вне- } \\
\text { сення «Марс-1» } \\
\text { дозами по } 0,8 \text { л/га }\end{array}$ & 110,0 & 106,5 & 92,5 & 15,9 & 2975 & 4357 & 2014 \\
\hline
\end{tabular}

Розміщення ділянок варіантів досліду систематичне. Регулятор росту «Марс-1» у відповідних дозах вносили обприскувачем ОП-2000-2-01 із розрахунку 300 л/га робочого розчину. Спостереження, аналізи та обліки проводили відповідно до загальноприйнятих методик, розроблених науковцями Інституту біоенергетичних культур і цукрових буряків НААНУ. У дослідах застосовувалася загальноприйнята для нашого регіону технологія вирощування буряка цукрового.

Результати досліджень. Загальновідомо, що технологія вирощування буряка цукрового $є$ однією із найбільш енерго- та матеріаломістких серед усіх сільськогосподарських культур, що вирощуються в Україні. Одним із головних аспектів цієї технології $є$ оптимальна густота рослин культури та рівномірне їх розміщення одна відносно одної. Зважаючи на це, програмою наших досліджень передбачалося вивчення впливу позакореневого внесення регулятора росту «Марс-1» на густоту рослин буряка цукрового та площу їх асиміляційної поверхні (табл. 1). Виходячи із даних таблиці 1, можна відмітити, що застосування регулятора росту мало стабілізаційний вплив на густоту рослин культури. Перед застосуванням препарату кількість рослин буряка цукрового на 1 га, в середньому за два роки, на всіх дослідних ділянках була майже однаковою i становила 109,6-110,2 тис./га. Вже через 30 днів після останнього внесення «Марс-1» облік густоти рослин показав, що вона почала зменшуватися, причому більш інтенсивно на контрольному варіанті, тобто там, де не вносили регулятора росту.
Найкраще характеризує позитивний вплив досліджуваного препарату на густоту рослин культури іiі облік саме перед збиранням врожаю. Зрозуміло, що через дію різних несприятливих факторів навколишнього середовища кількість рослин буряка цукрового до цього часу зменшиться, проте цей процес проходив менш інтенсивно саме на варіантах, де вносили регулятор росту «Марс-1». Кращим у цьому відношенні виявися варіант 3, де його вносили двічі дозами по 0,8 л/га. Саме на його ділянках перед збиранням врожаю, в середньому за два роки, виявилася найбільшою густота рослин - 92,5 тис./га і найменшою частка випавших біотипів - 15,9 \%. На контролі відповідні показники мали зворотну тенденцію: найменша густота і найбільший відсоток випавших рослин культури - 86,4 тис./га і 21,6\% відповідно.

Стосовно динаміки площі асиміляційної поверхні, то тут прослідковуються ті ж закономірності, що мали місце за обліку густоти рослин. Так, наприклад, облік асиміляційної поверхні перед збиранням врожаю показав, що на ділянках, де вносили «Марс-1», виявилася менша інтенсивність відмирання старих листків у рослин буряка, ніж на контролі.

Загальновідомо, що листок у рослини є фабрикою створення органічних речовин, які використовуються нею на різні ростові процеси. Збільшення площі листків і, відповідно, їх маси в кінцевому результаті приводить до збільшення маси коренеплоду, а отже, й продуктивності буряка цукрового в цілому. Саме тому програмою 


\section{СІЛЬСЬКЕ ГОСПОДАРСТВО. РОСЛИННИЦТВО}

наших досліджень передбачалося проведення обліку маси рослин культури (гички і коренеплодів) та їх цукристості залежно від застосування регулятора росту «Марс-1». Відповідні обліки проводили у три строки: 1 липня, 1 серпня і 1 вересня. Результати дворічних досліджень показали, що вже 1 липня можна було помітити незначну перевагу за масою гички i коренеплоду на досліджуваних варіантах порівняно $з$ контролем. Хоча, зауважимо, вміст цукрози у коренеплодах як на контролі, так i на варіантах, де вносили «Марс-1», ще був майже однаковим і становив у середньому 10,3-10,5 \%.

Облік відповідних показників маси рослин культури і вміст цукру в їх коренеплодах, що проводився 1 серпня, показав уже більш вагому перевагу за цими показниками саме досліджуваних варіантів.

Найваговитішими в цей час виявилися рослини буряка цукрового на третьому варіанті, де «Марс-1» вносили двічі. Вміст цукру у коренеплодах у цей час виявився мінімальним (13,4 \%) на ділянках контрольного варіанту. Третій варіант, як і сподівалися, виявився лідером за цим показником: саме тут коренеплоди рослин культури містили 14,0 \% цукру.

Станом на 1 вересня (коли востанне проводили облік маси рослин буряка цукрового та вміст цукру у їх коренеплодах) було відмічено таку ж тенденцію по відповідних показниках, як і під час попередніх обліків, хоча цього разу асиміляційна поверхня рослин культури почала інтенсивно зменшуватися - в цей час рослини буряка активно накопичували цукор.

Дані наших дворічних досліджень із вивчення впливу регулятора росту «Марс-1» на продуктивність цукроносної культури також показують позитивний вплив відповідного препарату на урожайність буряка цукрового (табл. 2).

Отже, позакореневе внесення регулятора росту «Марс-1» довело свою доцільність та ефективність. Найбільшу за два роки врожайність коренеплодів - 44,9 т/га - отримали на третьому варіанті, де вносили «Марс-1» двічі по 0,8 л/га. Така врожайність виявилася доказово вищою порівняно із варіантом, де цей препарат вносили один раз (46,2 т/га) та із контролем (42,4 т/га). Стосовно вмісту цукру в коренеплодах культури, то й цей показник виявився більшим на варіантах із «Марсом-1». Продовжуючи аналізувати дворічні дані відповідної таблиці, можна із впевненістю стверджувати, що дворазове позакореневе внесення регулятора росту «Марс-1» має найефективніший вплив на збільшення цукристості коренеплодів культури.

Під час збирання врожаю, коли й проводили цей аналіз, коренеплоди саме із третього варіанту мали (в середньому за два роки) цукристість на рівні 16,9\%, що на 0,3\% перевищило варіант 2 і на 0,8 \% контроль. Збір цукру - головний показник бурякоцукрового виробництва, за яким оцінюють ефективність того чи іншого агрозаходу, добрива чи препарату на посівах буряка цукрового.

Зрозуміло, що розрахунки цього показника також були обумовлені програмою наших досліджень. Зважаючи на це, слід зауважити, що разове позакореневе внесення «Марс-1» привело до отримання, в середньому за два роки, 7,07 т/га цукру, що на 0,82 т/га більше, ніж на контролі.

Проте, очевидно, що беззаперечним лідером по збору цукру протягом двох років досліджень виявився варіант із дворазовим застосуванням відповідного регулятора росту: саме ділянки цього варіанту дали по 7,59 т/га цукру.

\section{2. Вилив регулятора росту «Марс-1» на продуктивність буряка цукрового}

\begin{tabular}{|l|c|c|c||c|c|c||c|c|c|}
\hline \multirow{2}{*}{ Варіанти досліду } & \multicolumn{3}{|c||}{ Урожайність, т/га } & \multicolumn{3}{c||}{ Цукристість, \% } & \multicolumn{3}{c|}{ Збір цукру, т/га } \\
\cline { 2 - 11 } & $\begin{array}{c}2011 \\
\text { р. }\end{array}$ & $\begin{array}{c}2012 \\
\text { р. }\end{array}$ & $\begin{array}{c}\text { сере- } \\
\text { днє } \\
\text { за 2 } \\
\text { роки }\end{array}$ & $\begin{array}{c}2011 \\
\text { p. }\end{array}$ & $\begin{array}{c}2012 \\
\text { р. }\end{array}$ & $\begin{array}{c}\text { сере- } \\
\text { днє } \\
\text { за 2 } \\
\text { роки }\end{array}$ & $\begin{array}{c}2011 \\
\text { p. }\end{array}$ & $\begin{array}{c}2012 \\
\text { р. }\end{array}$ & $\begin{array}{c}\text { серед- } \\
\text { нє за 2 } \\
\text { роки }\end{array}$ \\
\hline $\begin{array}{l}\text { 1. Без застосування регулято- } \\
\text { ра росту (контроль) }\end{array}$ & 42,4 & 35,2 & 38,8 & 16,2 & 16,0 & 16,1 & 6,87 & 5,63 & 6,25 \\
\hline $\begin{array}{l}\text { 2. Одноразове внесення } \\
\text { «Марс-1» дозою 0,8 л/га }\end{array}$ & 46,2 & 39,0 & 42,6 & 16,8 & 16,4 & 16,6 & 7,76 & 6,4 & 7,07 \\
\hline $\begin{array}{l}\text { 3. Дворазове внесення } \\
\text { «Марс-1» дозами по 0,8 л/га }\end{array}$ & 48,5 & 41,3 & 44,9 & 17,1 & 16,7 & 16,9 & 8,29 & 6,90 & 7,59 \\
\hline НІР $_{0,5}$ & 2,12 & 1,84 & - & 0,16 & 0,20 & - & 0,48 & 0,64 & - \\
\hline
\end{tabular}


Висновок. У бурякосіючих господарствах зони нестійкого зволоження на посівах буряка цукрового доцільно проводити позакореневе внесення регулятора росту «Марс-1».

У цьому разі зростає продуктивність культури, значно покращуються технологічні якості

\section{БІБЛІОГРАФІЯ}

1. Анішин Л. О. Регулятори росту рослин: сумніви і факти // Пропозиція. - 2002. - № 5. C. 64-65.

2. Анішин Л. О. Вітчизняні біологічно активні препарати просяться на поля України // Пропозиція. - 2004. - № 10. - С. 48-50.

3. Засуха T. B. Вітчизняні регулятори росту рослин - це надійно // Пропозиція. - 2001. - № 3 . - C. 77.

4. Макрушин М. В. Регулятори росту - ефективний фактор підвищення продуктивності посі- коренеплодів і збільшується вихід цукру.

Застосовувати «Марс-1» варто двічі: перший раз - у фазі чотирьох пар справжніх листків, другий - перед змиканням листя у міжряддях. Доза для кожного внесення $-0,8$ л/га.

вів: зернових, овочевих, технічних та кормових культур // Пропозиція. - 2001. - № 5. - С. 60-64.

5. Макрушин М. В. Регулятори росту - важливий резерв підвищення врожайності // Пропозиція. - 2003. - № 2. - С. 71-73.

6. Пономаренко С.П. Біостимуляція в рослинництві - вагомий резерв урожаю 2009 р. // Агро Перспектива. - 2008. - № 8. - С. 34-35.

7. Черемха Б. М. Особливості застосування регуляторів росту рослин та їх ефективність // Пропозиція. - 2001. - №2. - С. 62-63. 